\title{
Contents, Vol. 41, 1979
}

\section{Contents}

No. 1

Original Paper

Tos, M. and Poulsen, G.: Tympanometry in 2-Year-Old Children. Seasonal Influence on Frequency of Secretory Otitis and Tubal Function 1

Fiellau-Nikolajsen, M. and Lous, J.: Tympanometry in Three-Year-Old Children. A Cohort Study on the Prognostic Value of Tympanometry and Operative Findings in Middle Ear Effusion 11

Ylikoski, J.; Collan, Y., and Palva, T.: Menière’s Disease: Morphological Findings in Eighth Nerve and Vestibular End Organs 26

Ylikoski, J.; Collan, Y., and Palva, T.: Functional and Histological Findings in Acoustic Neuroma 33

Ferlito, A. and Michau, C: Infantile Olfactory Neuroblastoma. A Clinicopathological Study with Review of the Literature 40

Gaafar, H.; Mandour, M., and El-Ghazzawi, E.: Electron Microscopic Study of Previ ously Irradiated Scleroma 51

Book Reviews 59

Varia 60

No. 2

Review Article

Clement, P.A.R. and Wolf, J.: Allergy in Otorhinolaryngology 61

Original Paper

Tos, M. and Bonding, P.: Treatment of Postinflammatory Acquired Atresia of the External Auditory Canal 85

Szathmary, I.; Simon, J.; Szobor, A., and Piffkó, P.: Myasthenia Gravis: the Effect of Tensilon ${ }^{\circledR}$ on the Caloric Nystagmus Response. Photoelectronystagmographic

Study 91

Contents

IV

Takemori, S.: Eye Movements Associated with Eye Closure. I. Normal Subjects. . . .

Takemori, S. and Yamada, S.: Eye Movements Associated with Eye Closure. II. Down Turning of Eye Ball Elevation

Book Reviews 107

No. 3

Original Paper

Böhmer, A. and Pfaltz, C.R.: On the Interaction of Vestibular and Optokinetic

Nystagmus in Man 121 
Mangabeira-Albernaz, P.L.; Malavasi Ganança, M.; Martinelli, M.C.; Ferreira Novo, N., and Rodrigues de Paiva, E.: Vestibular Decruitment. A Study of the Phenomenon in a Normal Population 135

Torok, N.: Pitfalls in Detecting Vestibular Decruitment with Air Calorics 143

Siegel, G.: Evidence for Selective Proliferation and Histological Localisation of B Lymphocytes in the Human Tonsil 147

Noda, Y.N.; Kurita, K.; Arakaki, Y.; Matayoshi, S.; Yoshikawa, S.; Nakama, T.; Kuniyoshi, M., and Kuniyoshi, M.: A Study on Dermatoses due to Tonsillar Focal Infection Using a Nation-Wide Questionnaire in Japan 158

Mann, W.: Diagnostic Ultrasonography in Paranasal Sinus Disease. A 5-Year Review . 168 Book Reviews $\quad 175$

Varia 176

No. 4

Original Paper

Rask-Andersen, H. and Stahle, J,: Lymphocyte-Macrophage Activity in the Endolymphatic Sac. An Ultrastructural Study of the Rugose Endolymphatic Sac in the Guinea Pig 177

Fiellau-Nikolajsen, M,: Tympanometry in 3-Year-Old Children. Type of Care as an Epidemiological Factor in Secretory Otitis Media and Tubal Dysfunction in Unselected Populations of 3-Year-Old Children 193

Huygen, P.L.M.: Nystagmometry: the Art of Measuring Nystagmus Parameters by Digital Signal Processing 206

Uddman, R. and Sundler, F.: Vasoactive Intestinal Polypeptide Nerves in Human Upper Respiratory Tract 221

Contents V

Afzelius, L.-E. and Rosen, C: Fractures of the Malar Bone. Follow-Up Study upon a Questionnaire 227

Willén, R.; Gad, A.; Willén, H.; Qvarnström, O., and Stahle, J.: Extracranial Meningioma Presenting as a Nasal Polyp 234

Varia 240

No. 5

Original Paper

Harrison, D.F.N.: Intrinsic Weakness of the TNM System for Classification of Laryngeal Cancer 241

Ganzer, U.: Cell Kinetic Aspects of Chemoradiotherapy in Laryngeal and Pharyngeal

Carcinomas 252

Guerrier, Y.: Difficult Indications for Partial Laryngectomy 262

Miehlke, A.; Chilla, R., and Vollrath, M.: Cryosurgery and Laser Surgery in the

Treatment of Malignant and Benign Laryngeal Processes 273

Meyer-Breiting, E. and Ilberg, C. von: Spread and Mode of Metastases of Supraglottic Laryngeal Carcinoma 288

Wey, W.: Suspicion of Persistent or Recurrent Carcinoma of the Larynx after Radia tion Therapy 301

Varia 312

No. 6

Original Paper 
Tos, M. and Poulsen, G.: Changes of Pars tensa in Secretory Otitis

Ivarsson, A.; Tjernström, Ö., and Uddman, R.: Patency of the Eustachian Tube in Different Body Positions 329

Lindström, J.; Tjellström, A., and Ejnell, H.: Juvenile Angiofibroma. Description of 7 Cases $\quad 341$

Podvinec, M. and Meran, A.: Neuro-Otological Aspects of Neurofibromatosis

Book Reviews

Varia 356

Subject Index $\quad 360$

Author Index 362 